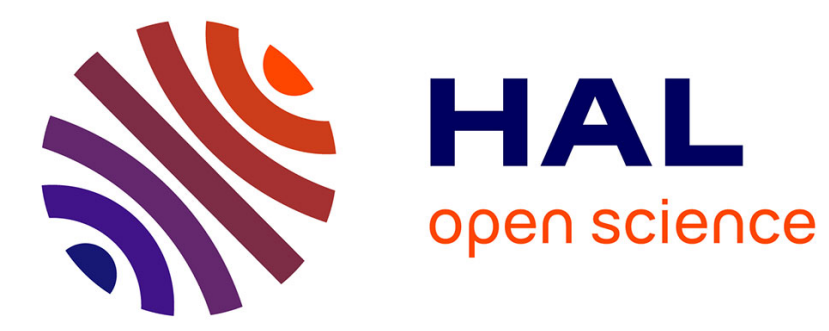

\title{
The bicausal relation between religion and income
}

Leon Bettendorf, Elbert Dijkgraaf

\section{To cite this version:}

Leon Bettendorf, Elbert Dijkgraaf. The bicausal relation between religion and income. Applied Economics, 2009, pp.1. 10.1080/00036840802600442 . hal-00582286

\section{HAL Id: hal-00582286 \\ https://hal.science/hal-00582286}

Submitted on 1 Apr 2011

HAL is a multi-disciplinary open access archive for the deposit and dissemination of scientific research documents, whether they are published or not. The documents may come from teaching and research institutions in France or abroad, or from public or private research centers.
L'archive ouverte pluridisciplinaire HAL, est destinée au dépôt et à la diffusion de documents scientifiques de niveau recherche, publiés ou non, émanant des établissements d'enseignement et de recherche français ou étrangers, des laboratoires publics ou privés. 


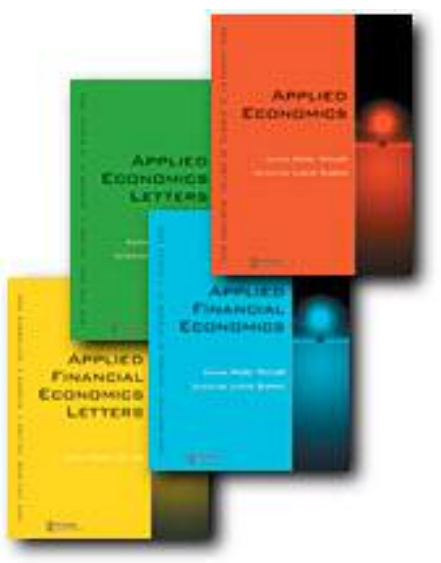

The bicausal relation between religion and income

\begin{tabular}{|r|l|}
\hline Journal: & Applied Economics \\
\hline Manuscript ID: & APE-07-0778.R1 \\
\hline Journal Selection: & Applied Economics \\
\hline Date Submitted by the \\
Author: & 09-Jul-2008 \\
\hline $\begin{array}{r}\text { Complete List of Authors: } \\
\text { JEL Code: }\end{array}$ & $\begin{array}{l}\text { Bettendorf, Leon; Erasmus University Rotterdam } \\
\text { Dijkgraaf, Elbert; Erasmus University Rotterdam, SEOR-ECRi } \\
\text { Distribution < D - Microeconomics }\end{array}$ \\
\hline Keywords: & Income, Religious Membership, Religious Participation \\
\hline
\end{tabular}

\section{(5) ScholarONE \\ Manuscript Central}




\title{
The bicausal relation between religion and income
}

\author{
L. Bettendorf* and E. Dijkgraaf ${ }^{\dagger \ddagger}$
}

9th July 2008

\begin{abstract}
In this paper the relation between religion and income is investigated using a micro-dataset for the Netherlands. Religion is measured by religious membership and by participation. Instead of estimating a religion equation and an income equation separately, joint regression is preferred since this generally yields more efficient estimates. Following the single-equation approach, both religious measures are found to decrease income significantly and income is found to affect religion negatively. However, these cross-effects become insignificant once the equations are estimated simultaneously. In contrast, the effects of socio-economic characteristics on religion and income hardly differ between the approaches.
\end{abstract}

Keywords: Income, Religious Membership, Religious Participation JEL classification: Z12, D31

\footnotetext{
${ }^{*}$ Erasmus University (H8-12), P.O. Box 1738, 3000 DR Rotterdam, The Netherlands. Phone: +31-10-4081808, bettendorf@few.eur.nl.

${ }^{\dagger}$ Corresponding author, SEOR-ECRi, Erasmus University (H 7-34), P.O. Box 1738, 3000 DR Rotterdam, The Netherlands. Phone: +31-10-4082590, Fax: +31-10-4089650, dijkgraaf@few.eur.nl, www.ecri.nl.

${ }^{\ddagger}$ We thank Rob Aalbers for helpful discussions at the start of the project and Richard Paap for his econometric advice. Comments of Albert van der Horst, Bertrand Melenberg, Jan Rouwendal and three anonymous referees have greatly improved the paper. In this research, data have been used from "Permanent Onderzoek Leefsituatie 2000" (Continuous Household Survey 2000) of Statistics Netherlands (CBS), which have been made available through the Scientific Statistical Agency.
} 


\section{Introduction}

Weber (1930) initiated a still lively discussion about the relation between religion and income. He argued that the Protestant, and especially Calvinistic, religion stimulated rational capitalism, resulting in a higher level of income for countries with a larger share of Protestants. This stimulus found its origin in the Protestant belief that work is a 'calling'. Fulfilment of the obligations to reap the fruits hidden in the created world, not asceticism, drives Protestants, in Weber's view. However, the evidence for this thesis is weak and alternative theories have emerged on how income is affected by religiousness. ${ }^{1}$

An alternative explanation for a positive effect stresses that a higher church attendance might expand social capital when churches are in fact civic organizations (Sacerdote and Glaeser, 2001). Network and interaction effects might in this case lead to more opportunities resulting in a higher level of income. ${ }^{2}$

According to Barro and McCleary (2003), belief is the crucial factor influencing income. In this view, church attendance increases income mainly through strengthening religious beliefs. However, a higher input to the religion sector (i.e. church attendance), while keeping the output (i.e. beliefs) constant, would then result in a negative effect on income as fewer resources are available for productive activities (see also Azzi and Ehrenberg, 1975).

Furthermore, religion might reduce the utility derived from income. If a religion stresses the value of 'good works', like the Roman Catholic religion for example, the value of income is reduced. ${ }^{3}$ This theory would also predict a lower level of income for religious people.

Given the different arguments, the effect of religion on income is undetermined. Empirical analysis is necessary to test which effects dominate. The empirical literature on income effects of religion

\footnotetext{
${ }^{1}$ See Iannaccone (1998) for a thorough introduction to the economics of religion.

${ }^{2}$ Gruber (2005) shows with US micro-data that both religious participation and income are higher when a larger share of the local population is of an individual's religion.

${ }^{3}$ Lelkes (2006) shows with micro-data for Hungary that income is a less important source of happiness for people who are actively involved in religious activities.
} 
is summarized in Table $1 .^{4}$ Almost all studies focus on the differences in effect between denominations (Jewish, Catholic, Protestant, etc.). Crain and Lee (1999) and Lipford and Tollison (2003), however, analyze the effect of church membership without distinguishing denominations. With the exception of Steen (1996), only recently has the participation effect of religious behavior been empirically tested (Cornwell et al., 2003, Barro and McCleary, 2003 and Mangeloja, 2005). Until the cross-country studies of Barro and McCleary (2003) and Mangeloja (2005), all results were based on data for Canada and the USA. The results are always positive for the Jewish belief. More mixed results are found for other denominations and for participation. Interestingly, Mangeloja (2005) also presents estimations with time series for eight OECD countries. He finds that the effect of religion on income growth is not consistent between countries. While he finds an insignificant effect of religion on income growth for five countries, other countries show a negative or positive effect.

A second strand of the literature analyzes the reverse relation, i.e. the effect of income (and other socio-economic characteristics) on religion. According to Iannaccone (1998) this literature finds a strong positive relation between income and financial contributions to churches, but often a weak relation with other religious variables (attendance, membership, frequency of prayer and beliefs). Sawkins et al. (1997), for instance, find an insignificant relationship between non-labor income and church attendance using micro-data for Great Britain. The coefficients for labor earnings variables, however, imply higher church attendance for middle-income earners.

Although these two types of analyses suggest that there might be a bicausal relationship between religion and income, most studies ignore the endogeneity of religion. As long as the role of endogeneity is unclear, the general conclusions of the literature can be questioned, as neglect of endogeneity might result in biased estimations. One exception is Lipford and Tollison (2003). They estimate a system of equations to account for the effect of church membership on income but also for the reverse effect. They find that not only the estimated effect of church membership on income is

\footnotetext{
${ }^{4}$ Other effects are also analyzed in the literature such as effects on mental and physical health, crime and divorce. See Iannaccone (1998) for an excellent overview.
} 
Table 1: Literature income and religion

\begin{tabular}{|c|c|c|c|c|}
\hline No. & Country & Level of data & Measure of religion & Effect on income \\
\hline 1. & USA & Micro: men & Membership & Positive (Jewish) \\
\hline 2. & Canada & Micro: men & Membership & Insignificant (within memberships) \\
\hline \multirow[t]{2}{*}{3.} & Canada & Micro: men & Membership & Positive (Jewish) \\
\hline & & & & Insignificant (Protestants vs. Catholics) \\
\hline 4. & USA & Micro: men & Membership & Positive (Jewish) \\
\hline \multirow[t]{4}{*}{5.} & USA & State & Membership & Positive (Jewish) \\
\hline & & & & Insignificant (liberal Protestant) \\
\hline & & & & Negative (Catholic and orthodox \\
\hline & & & & Protestant) \\
\hline \multirow[t]{4}{*}{6.} & USA & Micro: Men & Membership & Positive (Jewish and Catholic) \\
\hline & & & & Insignificant (Protestants) \\
\hline & & & Participation & Negative (Protestants) \\
\hline & & & & Insignificant (other memberships) \\
\hline 7. & USA & State & Membership & Insignificant \\
\hline 8. & USA & State & Membership & Negative \\
\hline \multirow[t]{2}{*}{9.} & USA & Micro: women & Membership & Insignificant (on pay per hour) \\
\hline & & & Participation & Positive (on hours worked) \\
\hline \multirow[t]{3}{*}{10.} & Several (max. 58) & Country & Membership & Negative \\
\hline & & & Participation & Negative \\
\hline & & & Beliefs & Positive \\
\hline \multirow[t]{6}{*}{11.} & Eight OECD & Country & Participation & Positive (1 country) \\
\hline & & & & Negative (2 countries) \\
\hline & & & & Insignificant ( 5 countries) \\
\hline & & & Beliefs & Positive (2 countries) \\
\hline & & & & Negative (1 country) \\
\hline & & & & Insignificant ( 5 countries) \\
\hline
\end{tabular}

1. Chiswick (1983), 2. Tomes (1984), 3. Tomes (1985), 4. Chiswick (1993), 5. Heath et al. (1995),

6. Steen (1996), 7. Crain and Lee (1999), 8. Lipford and Tollison (2003), 9. Cornwell et al. (2003),

10. Barro and McCleary (2003), 11. Mangeloja (2005). 
negative, but also the effect of income on church membership. Furthermore, the estimate of the former effect is twice that with single-equation estimation.

Barro and McCleary (2003) also take the endogeneity issue seriously. ${ }^{5}$ They account for this problem by using instrumental variables in a three-stage least squares estimation. Again they find that endogeneity is important and that correcting for this problem results in larger coefficients with the same sign. They find that religion influences income growth negatively when measured by church attendance and positively when measured by beliefs (in hell and heaven).

While Lipford and Tollison (2003) use a state-level database with 153 observations for the USA, Barro and McCleary (2003) use a panel database with 181 observations for 59 countries. This paper analyzes a micro-dataset for the Netherlands with observations for 27,908 households. We find that whether we estimate the income and the religion equations separately or simultaneously matters for the results. While religiousness is found to reduce income significantly when single equations are estimated, joint estimation results in an insignificant effect. ${ }^{6}$

The contribution to the literature of this paper is threefold. First, we estimate the bicausal relation between religion and income for the Netherlands while the literature is dominated by results for the USA and Canada. Second, our dataset allows us to discriminate between the effects of religious membership and of religious participation. Third, we show with micro-data that the equations should be estimated jointly to explain the relation between religion and income.

The next two sections discuss the estimation methodology and the data. Section IV describes the estimation results. The last section concludes.

\footnotetext{
${ }^{5}$ See also McCleary and Barro (2006).

${ }^{6}$ Notice that even in the absence of a serious endogeneity problem, system estimation yields generally more efficient estimates by using the correlation of the disturbance terms.
} 


\section{Methodology}

We start by estimating the relation between religion measured by church membership and income. As both variables are measured as discrete variables, a probit estimator is applied. Membership is denoted by the dummy $y_{1 i}$ with the value 1 if household $i$ is a member of a church. As income is available only in deciles, ${ }^{7} y_{2 i}$ denotes the after-tax income class of household $i$. The system of structural equations is expressed in terms of the latent variables. This specification assumes that households have complete flexibility in their decisions but that the researcher can only observe the choices as discrete variables (see Blundell and Smith, 1994). ${ }^{8}$ The structural model written in terms of the latent variables $\left(y_{1}^{*}\right.$ and $\left.y_{2}^{*}\right)$ and vectors of socio-economic control variables $\left(x_{1}\right.$ and $\left.x_{2}\right)$ is:

$$
\begin{array}{ll}
y_{1 i}^{*}=\alpha_{1} y_{2 i}^{*}+\beta_{1}^{\prime} x_{1 i}+u_{1 i} & y_{1 i}=1 \quad \text { if } y_{1 i}^{*}>0,=0 \text { otherwise } \\
y_{2 i}^{*}=\alpha_{2} y_{1 i}^{*}+\beta_{2}^{\prime} x_{2 i}+u_{2 i} & y_{2 i}=j \quad \text { if } \mu_{j-1}<y_{2 i}^{*} \leq \mu_{j} \quad j=1, ., J
\end{array}
$$

The second equation contains $J+1$ cutoffs $\mu_{j}$. Assuming that $y_{2}^{*}$ has an infinite support yields that $\mu_{0}=-\infty$ and $\mu_{J}=\infty$. Since $x_{2}$ includes a constant, $\mu_{1}=0$ has to be imposed. The remaining $J-2$ cutoffs are estimated.

Model (II.1) cannot be directly estimated since it contains non-observables on the right-hand side. Therefore, the reduced form equations are derived as, with $D \equiv\left(1-\alpha_{1} \alpha_{2}\right)$,

$$
\begin{array}{lll}
y_{1 i}^{*}=\bar{\beta}_{1}^{\prime} x_{i}+v_{1 i} & \bar{\beta}_{1}^{\prime} x_{i}=\left(\beta_{1}^{\prime} x_{1 i}+\alpha_{1} \beta_{2}^{\prime} x_{2 i}\right) / D & v_{1 i}=\left(u_{1 i}+\alpha_{1} u_{2 i}\right) / D \\
y_{2 i}^{*}=\bar{\beta}_{2}^{\prime} x_{i}+v_{2 i} & \bar{\beta}_{2}^{\prime} x_{i}=\left(\alpha_{2} \beta_{1}^{\prime} x_{1 i}+\beta_{2}^{\prime} x_{2 i}\right) / D & v_{2 i}=\left(\alpha_{2} u_{1 i}+u_{2 i}\right) / D
\end{array}
$$

where $x_{i}=x_{1 i} \cup x_{2 i}$. A variable that occurs in both structural equations thus has a coefficient equal to $\left(\beta_{1}+\alpha_{1} \beta_{2}\right) / D$ and $\left(\alpha_{2} \beta_{1}+\beta_{2}\right) / D$ in the reduced form equations, respectively. Identification

\footnotetext{
${ }^{7}$ Statistics Netherlands calculates deciles from the original level of data for privacy reasons.

${ }^{8}$ Maddala (1983, p. 124) interprets a latent variable as a measure of intentions. Blundell and Smith (1994) consider a class of structural models that are simultaneous in the observed dependent variables. As a consequence, the reduced form cannot be derived explicitly and extra coherency restrictions have to be imposed.
} 
of the structural coefficients requires that $x_{1}$ contains at least one variable that is not included in $x_{2}$ and vice versa. The reduced form disturbances $v_{k}$ are assumed to have a joint normal distribution with means 0 , variances 1 , and covariance $\rho .{ }^{9}$ To compare the results of the system estimation, we also apply a probit regression to each equation separately. The single equations are specified similarly to (II.1), where the latent variable $y_{k}^{*}$ on the right-hand side is replaced by the observed $y_{k} \cdot{ }^{10}$ The estimation procedure is explained in Appendix A.

In the estimation of a second system, religiousness is measured by church attendance. The binary $y_{1}$ is replaced by a dummy with the value 1 if the household attends church services at least once a week. The vector of control variables $(x)$ in this system contains dummies indicating the denomination to which the respondent belongs. One could argue that the choice of denomination should also be treated as an endogenous decision. However, this last option implies in our case simultaneous estimation of three equations (two ordered probits for income and denomination membership and one probit for participation). As this clearly results in econometric complexities, simplification is desirable.

This is motivated by the intuitive observation that endogeneity is a more serious problem with participation than with membership choice, as most people stick to the church membership they are born with, while participation is changed far more often. Indeed, Tomes (1984) shows that more than $75 \%$ of Canadians keep the religion they are raised in (this figure is $86 \%$ for Protestants and $81 \%$ for Catholics). In contrast, a majority of the people that are not raised in a religion become members of a church later on (53\%). Figures for the Netherlands are in accordance with this observation (Becker and De Wit, 2000). ${ }^{11}$ While membership did not change much between 1991 (43\%) and 1999 (37\%), religious participation (defined as the share of members attending services at least once a week) decreased by $26 \%$. This was especially the case for Roman Catholics,

\footnotetext{
${ }^{9}$ This implies that the structural disturbances $u_{k}=v_{k}-\alpha_{k} v_{k^{\prime}}\left(k \neq k^{\prime}\right)$ are normally distributed with means 0 , variances $\left(1+\alpha_{k}^{2}-2 \alpha_{k} \rho\right)$ and covariance $\left(1+\alpha_{1} \alpha_{2}\right) \rho-\alpha_{1}-\alpha_{2}$.

${ }^{10}$ Note that the rejection of the hypothesis $\rho=0$ means that system estimation is preferred to single-equation regressions.

${ }^{11}$ Our dataset contains no information about the religion in which a person was raised.
} 
for whom this share decreased by $53 \%$ to a level of $14 \%$ in $1999 .{ }^{12}$

It should be noted that one can doubt the quality of the answers on the membership question because official but inactive members, who make up a large part of total members, might answer this question arbitrarily with yes or no. Answers on questions about participation are considered to be more precise. We therefore believe that the participation variable is a more reliable measure of religiousness.

\section{Data}

Data are from 2000 for 27,908 Dutch households. These data are based on a survey of Statistics Netherlands (CBS), which gives, according to the CBS, a reliable picture of the total Dutch population. In this survey households are questioned about socio-economic characteristics (such as age, education level and composition of households), the level of after-tax household income ${ }^{13}$ and church membership.

The income tax is in principle levied on individual income. However, fiscal partners can transfer joint income components between them for their tax return. Benefits that are means tested are based on household income. ${ }^{14}$ Specific church taxes are not levied in the Netherlands. Tax refunds arising from contributions to churches are not included in our income concept.

Households can choose between no membership of a denomination or membership of the following denominations: Roman Catholic, two types of Protestants (Reformed and 'Gereformeerd'), Islam and non-specified other denominations. ${ }^{15}$ Furthermore, members of a denomination are asked how many times per year they attend a service of that denomination. Membership and frequency

\footnotetext{
12 This is in line with the conclusion of Iannaccone (1998, p. 1470) that the empirical literature shows that for religious membership, 'income or wage effects are almost always dwarfed by those of age, gender, and religious upbringing.'

${ }^{13}$ We have no information on the wage rate or hours of work.

${ }^{14}$ Detailed information can be found in De Mooij (2006, Section 3.4) and on the Ministry of Finance website (www.minfin.nl/en/subjects,taxation/income-tax).

15 The Reformed Church and the 'Gereformeerde' Church are both Protestant churches. Although they are alike in some respects, the differences are large in others. Tests show that it is not appropriate to combine them in one Protestant dummy (orthodox Protestants are included in the dummy for the Reformed Church). Reformed households are taken as benchmark in the estimation, so the dummy for this religion is excluded.
} 
of attendance are unfortunately not reported for individual family members, but only for the respondent (always an adult). This study therefore focuses on the question of whether household income is different when at least the respondent is religious. Ideally, we would need information on the religious behavior of all household members, but these data are not available. In our opinion this limitation is not crucial for our estimations as homogeneous religiousness within households is still the rule, especially for membership. Kalmijn (1998) concludes on the basis of several studies for western countries that both Catholics and Protestants have a tendency to marry within rather than outside their group. Hendrickx (1998) confirms this for the Netherlands.

Our estimations are based on two different datasets (Table 2). The full dataset (27,908 observations) is used to estimate the system with membership as endogenous variable. As here religion is defined as membership of a church, we include observations for church members $(16,758)$ as well as for non-church members $(11,150)$. These latter observations are excluded in the second system estimation, with participation as endogenous variable, as non-church members have zero participation by definition. Since the non-church-member dummy would be perfectly correlated with participation $(=0)$, estimation of the corresponding coefficient in the first equation is impossible. Estimation of the income equation would suffer from multicollinearity for the same reason.

In total 16,758 respondents are members of some denomination (see Table 3 ). This is $60 \%$ of all households, which is comparable to the figure for the USA according to Iannaccone (1994). Roman Catholic membership applies for $52 \%$ of all members, while $36 \%$ are members of a Protestant church. Finally, $4 \%$ are members of the Islamic faith and $9 \%$ of some non-specified denomination. Comparing the number of church members who seldom or never attend services $(7,366)$ with total membership of denominations makes it clear that many members are not religiously active. While this comprises $44 \%$ of total church members, the differences between denominations are large, with members of the Roman Catholic, Reformed and Islamic denominations having the lowest participation levels. Only $21 \%$ of church members attend a church service often (once or more per week). This is somewhat lower than in Canada and much lower than in the USA, according to 
Table 2: Descriptive statistics: income and socio-economic characteristics

\begin{tabular}{|c|c|c|c|c|c|c|c|c|}
\hline & \multicolumn{4}{|c|}{ Sample members } & \multicolumn{4}{|c|}{ Full sample } \\
\hline & Ave. & St. dev. & Max. & Min. & Ave. & St. dev. & Max. & Min. \\
\hline Income (decile) & 5.43 & 2.81 & 10 & 1 & 5.57 & 2.84 & 10 & 1 \\
\hline Member $_{\text {Catholic }}$ & 0.52 & 0.50 & 1 & 0 & 0.31 & 0.46 & 1 & 0 \\
\hline Member $_{\text {Reformed }}$ & 0.24 & 0.42 & 1 & 0 & 0.14 & 0.35 & 1 & 0 \\
\hline Member $_{\text {Gereformeerd }}$ & 0.12 & 0.32 & 1 & 0 & 0.08 & 0.25 & 1 & 0 \\
\hline Member Islam $_{\text {Ist }}$ & 0.04 & 0.20 & 1 & 0 & 0.02 & 0.15 & 1 & 0 \\
\hline Member $_{\text {Other }}$ & 0.09 & 0.28 & 1 & 0 & 0.05 & 0.22 & 1 & 0 \\
\hline Age & 49.42 & 15.35 & 85 & 15 & 47.57 & 14.97 & 85 & 15 \\
\hline Male & 0.82 & 0.38 & 1 & 0 & 0.81 & 0.39 & 1 & 0 \\
\hline Household size & 2.91 & 1.38 & 6 & 1 & 2.86 & 1.34 & 6 & 1 \\
\hline Child $_{<4}$ years & 0.16 & 0.37 & 1 & 0 & 0.17 & 0.37 & 1 & 0 \\
\hline Child $_{4-12}$ years & 0.16 & 0.36 & 1 & 0 & 0.16 & 0.37 & 1 & 0 \\
\hline Child $_{12-18 \text { years }}$ & 0.11 & 0.31 & 1 & 0 & 0.10 & 0.31 & 1 & 0 \\
\hline Single-adult household & 0.18 & 0.38 & 1 & 0 & 0.19 & 0.39 & 1 & 0 \\
\hline Education $_{\text {low }}$ & 0.06 & 0.24 & 1 & 0 & 0.06 & 0.24 & 1 & 0 \\
\hline Education $_{\text {mid }}$ & 0.34 & 0.47 & 1 & 0 & 0.34 & 0.47 & 1 & 0 \\
\hline Education $_{h i g h}$ & 0.22 & 0.41 & 1 & 0 & 0.25 & 0.43 & 1 & 0 \\
\hline Dutch & 0.97 & 0.18 & 1 & 0 & 0.97 & 0.16 & 1 & 0 \\
\hline Surface per inhabitant & 3.25 & 1.25 & 5 & 1 & 3.08 & 1.29 & 5 & 1 \\
\hline
\end{tabular}

Table 3: Descriptive statistics: number of denomination members

\begin{tabular}{lr|rrrrr}
\hline & & \multicolumn{5}{|c}{ Participation: } \\
Membership & All & 52 & 24 & 12 & $<12$ & $\approx 0$ \\
\hline Roman Catholic & 8,655 & 882 & 641 & 1,043 & 1,979 & 4,110 \\
Reformed & 4,041 & 860 & 376 & 287 & 502 & 2,016 \\
'Gereformeerd' & 1,944 & 951 & 259 & 134 & 167 & 433 \\
Islam & 678 & 212 & 35 & 35 & 78 & 318 \\
Other & 1,440 & 608 & 131 & 74 & 138 & 489 \\
Total & 16,758 & 3,513 & 1,442 & 1,573 & 2,864 & 7,366 \\
\hline
\end{tabular}


Iannaccone et al. (1997). Countries such as Switzerland, Australia, Germany, New Zealand and the UK have a somewhat lower attendance rate, while Scandinavian countries especially have a very low religious participation rate (less than 10\%). In our estimations the participation dummy is based on the category of church visits of at least once per week. Our results do not depend on this definition. When participation is defined as church attendance at least twice per month, results are comparable. In another alternative, we treat households that never attend services as non-church members. This reclassification also hardly affects our conclusions. ${ }^{16}$

Table 4 gives more information about the income deciles. Although we only have information on which decile households are in, average and maximum decile figures in euros are available. The average income for our sample is 24,800 euro per year. The distribution of households over the deciles is quite equal with a minimum of 2,508 and a maximum of 2,872 households per decile. The table also shows the number of non-church-member households per decile (column with Membership=0) and the number of households that are church members (Membership=1), divided into members who participate less than once a week $($ Part $=0)$ and members who participate at least once a week $($ Part $=1)$.

Data are available for the most important socio-economic characteristics (see Appendix B for definitions). For most characteristics information is expressed as a dummy variable. Exceptions are age (available for the breadwinner and included in years and its square), household size (the number of persons in the household) ${ }^{17}$ and surface per inhabitant (ordered variable with value 1 for a densely populated area and 5 for a sparsely populated country village). Dummies are available for four types of family composition (benchmark is households with two adults and no children under 18 years old), for four education levels (benchmark is households with an education level less than low) and for the breadwinner being of Dutch nationality (benchmark is households with breadwinner not of Dutch nationality).

\footnotetext{
${ }^{16}$ Results for both sensitivity analyses are available on request and are also included in Bettendorf and Dijkgraaf (2005).

${ }^{17}$ Statistics Netherlands does not report data for households consisting of more than 6 persons for privacy reasons.
} 
Table 4: Income deciles

\begin{tabular}{|c|c|c|c|c|c|c|}
\hline \multirow{3}{*}{$\begin{array}{l}\text { Income } \\
\text { decile }\end{array}$} & \multicolumn{4}{|c|}{ Number of households } & \multicolumn{2}{|c|}{ Income in euros per year } \\
\hline & \multicolumn{2}{|c|}{ Membership $=1$} & \multirow{2}{*}{$\begin{array}{r}\text { Member- } \\
\text { ship }=0\end{array}$} & \multirow[b]{2}{*}{ Total } & \multirow[b]{2}{*}{ Average } & \multirow[b]{2}{*}{ Maximun } \\
\hline & Part $=1$ & Part $=0$ & & & & \\
\hline 1 & 357 & 1,137 & 1,014 & 2,508 & 4,900 & 10,000 \\
\hline 2 & 465 & 1,315 & 897 & 2,677 & 11,500 & 12,900 \\
\hline 3 & 502 & 1,296 & 1,018 & 2,816 & 14,300 & 15,700 \\
\hline 4 & 416 & 1,348 & 1,082 & 2,846 & 17,100 & 18,700 \\
\hline 5 & 386 & 1,372 & 1,095 & 2,853 & 20,500 & 22,200 \\
\hline 6 & 320 & 1,397 & 1,155 & 2,872 & 24,100 & 25,900 \\
\hline 7 & 308 & 1,386 & 1,178 & 2,872 & 27,900 & 29,900 \\
\hline 8 & 276 & 1,408 & 1,150 & 2,834 & 32,400 & 35,100 \\
\hline 9 & 275 & 1,309 & 1,252 & 2,836 & 38,700 & 43,200 \\
\hline 10 & 208 & 1,277 & 1,309 & 2,794 & 56,500 & na \\
\hline Total & 3,513 & 13,245 & 11,150 & 27,908 & & \\
\hline
\end{tabular}

\section{Results}

First we discuss the estimation results for the bicausal relation between religious membership and income. The second subsection presents the results for religious participation. The third subsection discusses results for the socio-economic characteristics.

\section{IV.1 Membership and income}

Table 5 presents the estimation results for religion defined as membership of a denomination. In panel A the results are given for the membership equation, while in panel B the results are shown for the income equation. Columns two and three present the structural coefficients and the standard errors, while the fourth column gives marginal effects. ${ }^{18}$ The system results can be compared with the results for the single-equation estimations, presented in the last two columns. The choice of the identifying restrictions is motivated by the single-equation results. In the system estimation, the Male dummy is excluded from the membership equation, while the Child ${ }_{12-18}$ dummy is dropped

\footnotetext{
${ }^{18}$ Marginal effects on income are calculated in euros using the average income per decile from Table 4 and expressed as a $\%$ of the sample average income. The marginal effects of age are multiplied by its standard deviation $(=15)$ for a better scaling. See Bettendorf and Dijkgraaf (2005) for details on the computation and for individual decile effects. These results are also available on request.
} 
from the income equation. ${ }^{19}$

A first finding is that $\rho$ is significant (at 1\%). ${ }^{20}$ The results of the system estimation are therefore preferred to the single-equation estimations. The single-equation approach results in highly significant, negative cross-effects between membership and income. The significant bicausal relation is no longer found with the more efficient simultaneous estimation. The structural estimates show that for given socio-economic variables income has no effect on membership. The negative coefficient in the single membership equation incorrectly identifies part of the non-income effects as pure income effects. A similar interpretation holds for the income equation. The rejection of bicausality might suggest that system estimation is not required. However, system estimation still yields more efficient estimates than single-equation estimation since it accounts for the correlation between the disturbance terms of both equations.

In contrast, Lipford and Tollison (2003) found that system estimation did not change the significant, negative effect of income on membership, but that the negative coefficient for the opposite effect doubled. The negative relation between membership and income in both directions is not found in our dataset.

\section{IV.2 Participation and income}

Table 6 presents the estimation results for religious participation. The identifying restrictions are the same as in the first system (with membership as religious measure). Again, $\rho$ is significant. With single-equation estimation, both the coefficient for the effect of income on participation and the coefficient for the opposite effect are significantly negative. However, estimating a system again yields insignificant cross-effects, suggesting that households who attend church services frequently do not have a significantly lower income. Concerning the reverse effect, Iannaccone (1998) reports that most studies find that income is a weak predictor of church attendance.

\footnotetext{
${ }^{19}$ Sensitivity analyses with other restrictions show that our main conclusions do not depend on this choice. Alternative identifying restrictions are motivated by the significance level or the magnitude of marginal effects in the single-equation estimation. Results are available upon request.

${ }^{20}$ For both the membership and participation estimations this result is confirmed by a log likelihood ratio test.
} 
Table 5: Estimation results: religious membership

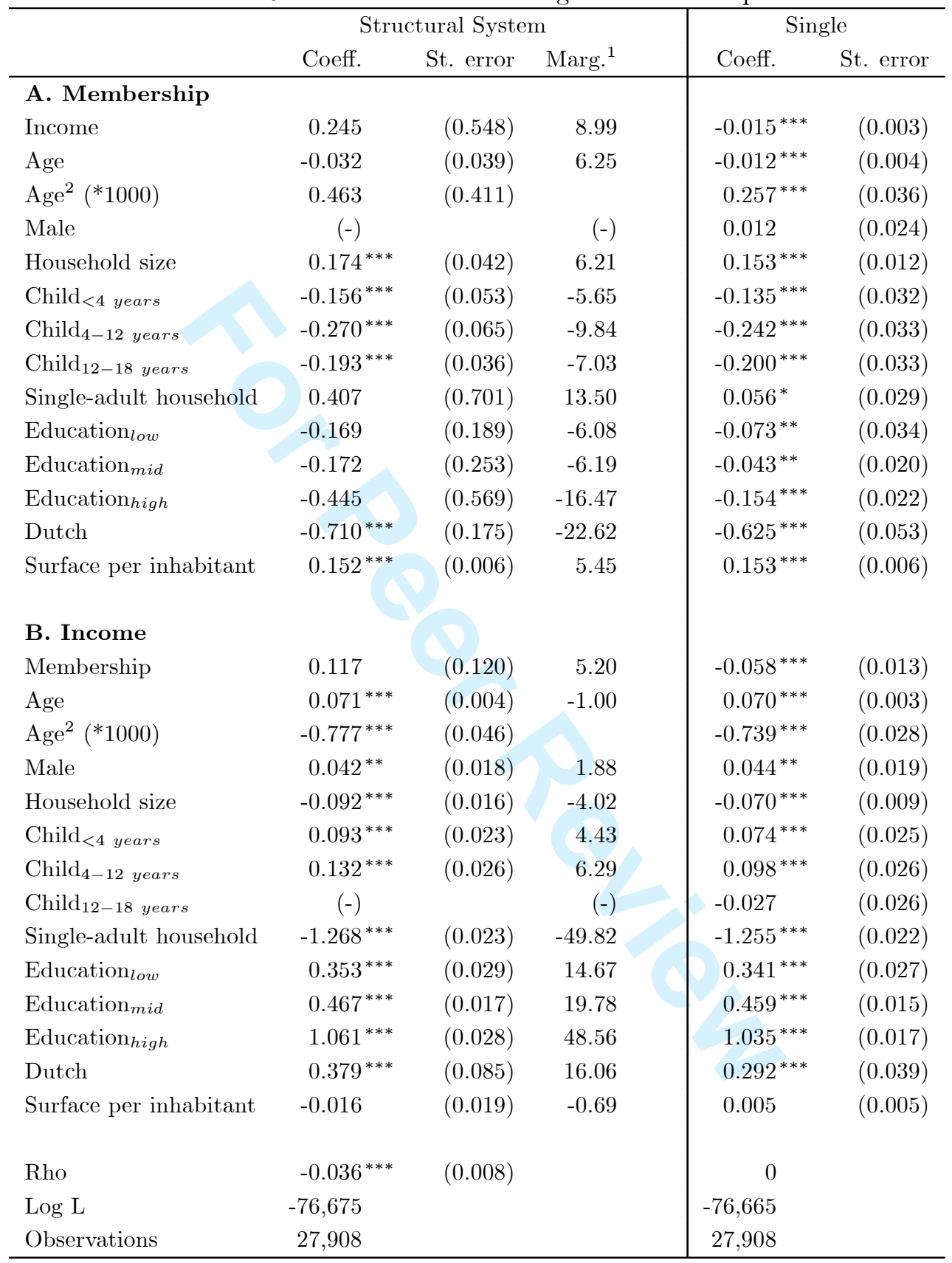

1. Marginal effects in \%-point change of base value for Membership (60.34\%) and $\%$ change of base value for Income (24.8 thousand euro). Quadratic and linear effect of age are combined in one marginal effect.

Coefficients with $* / * * / * * *$ are significant at the $10 \% / 5 \% / 1 \%$ level. 
Interestingly, we find an effect of Islamic membership on income after controlling for religious participation. Compared with the benchmark (a Reformed household), Islamic households have less income (-25\%). This effect is in accordance with results found by Barro and McCleary (2003), although our effects are much larger. It should be kept in mind that part of this large effect probably has to do with the specific labor market position of persons coming from Islamic countries. ${ }^{21}$ The insignificant effect of Catholic membership on income is in line with Cornwell et al. (2003). However, Heath et al. (1995) found a negative effect and Steen (1996) found a positive effect for this variable.

Summarizing, our analysis shows that estimating a single equation may lead to erroneous conclusions about the effect of religion on income. Clearly, the conclusions of Lipford and Tollison (2003) and Barro and McCleary (2003) cannot be confirmed for our data as in their cases the effect remains significantly negative after correcting for endogeneity. The significant effects found in Cornwell et al. (2003) and Steen (1996) might be misleading since they follow the single-equation approach. Our results are more in line with Mangeloja (2005) as he finds insignificant effects for five out of eight countries using country-level data. The effect of religion on income probably differs between countries, making cross-country analysis a troublesome route to follow.

\section{IV.3 Effects of socio-economic characteristics}

In contrast to the former findings, system estimation hardly affects the coefficients representing the effects of socio-economic characteristics. This is illustrated by way of the marginal effects calculated for the case with religious participation (Figures 1 and 2). ${ }^{22}$ Two features can be observed. First, the marginal effects obtained for the structural system hardly differ from the ones for the reduced system (if the corresponding coefficient is significantly estimated). In other words, the direct effect of the socio-economic characteristics dominates the indirect effects for both endogenous variables.

\footnotetext{
${ }^{21}$ Sensitivity analysis shows that all conclusions are robust when data from Islamic members are excluded. Results are available on request.

${ }^{22}$ See Bettendorf and Dijkgraaf (2005) for details on the computation and for detailed effects. These results are also available on request.
} 
Table 6: Estimation results: participation (once or more per week)

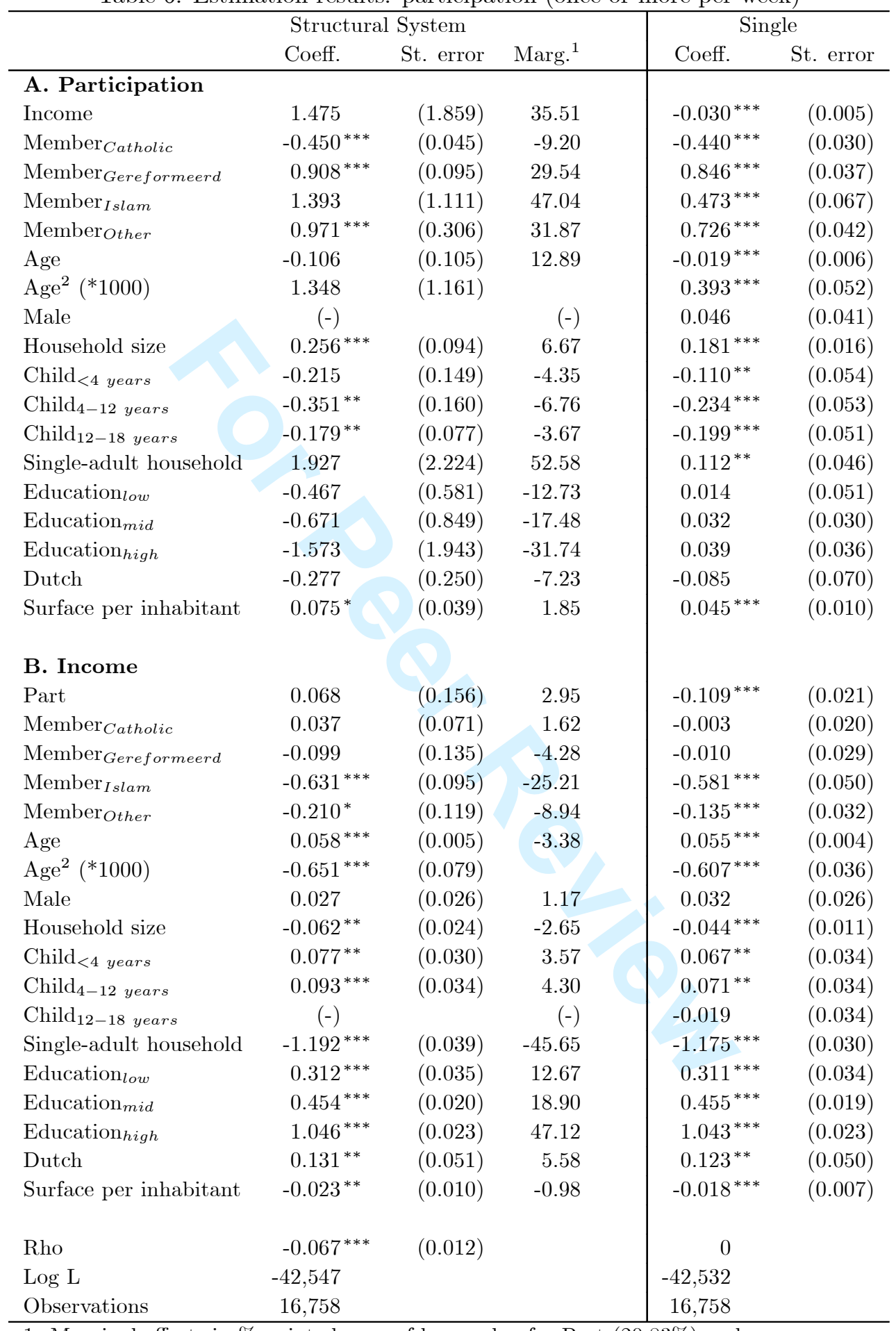

1. Marginal effects in \%-point change of base value for Part (20.83\%) and $\%$ change of base value for Income (24.8 thousand euro). Quadratic and linear effect of age are combined in one marginal effect.

Coefficients with $* / * * / * * *$ are significant at the $10 \% / 5 \% / 1 \%$ level. 

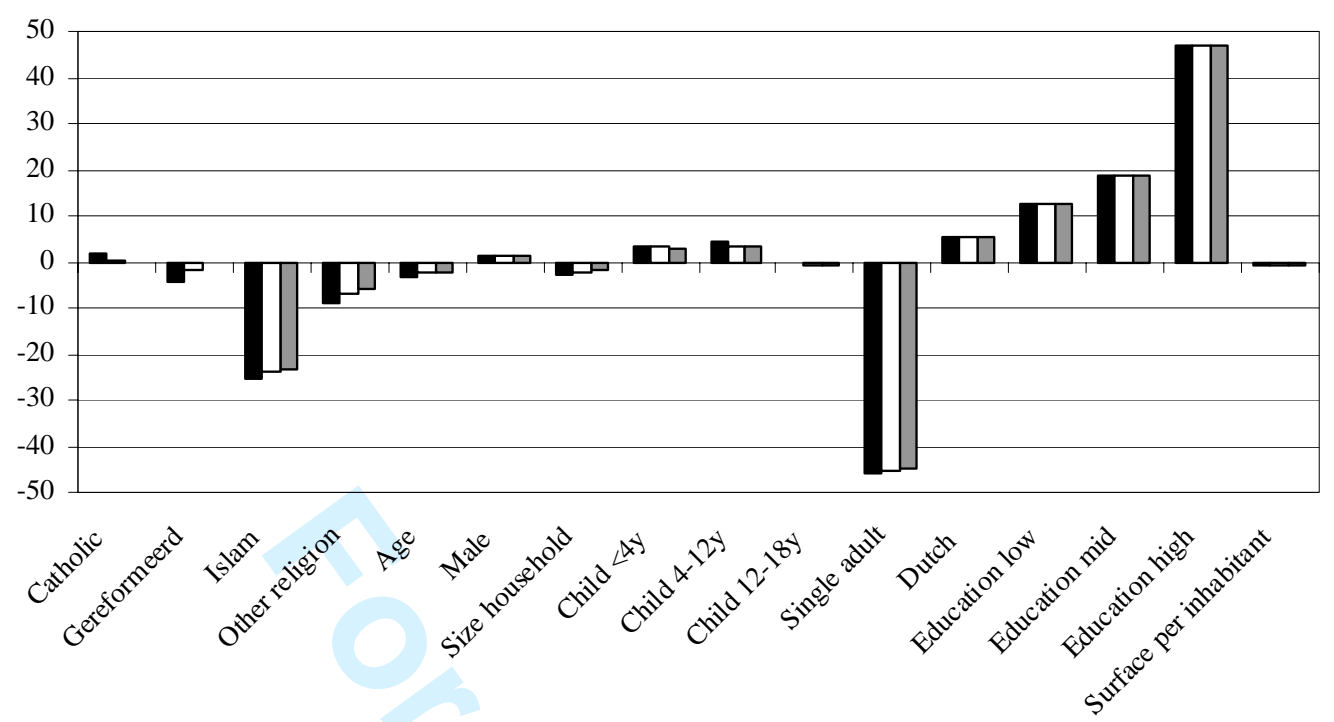

- Structural $\square$ Reduced $\square$ Single

Figure 1: Marginal effects of Income equation for Participation case (\% of average income)

Second, system estimation yields effects comparable to those from single-equation estimation. In the following we discuss in detail the structural coefficients of the socio-economic variables.

The effects of socio-economic control variables on income are in general as expected (see Panel B in Tables 5 and 6). Income increases with the level of education and the age profile has an inverted U-shape (with a peak at 46 and 44 years, respectively). ${ }^{23}$ Households with a male breadwinner have higher income levels (only significant in Table 5). Larger households have a lower level of income, although there is some indication that households with children under 12 have more. Households with one adult have less income than households with two grown-ups without children (remember that our endogenous variable is household income). Finally, there is some indication that Dutch households have more income than non-Dutch households and that households living in more densely populated areas have higher incomes.

The marginal effects on income are modest for most variables, except for single-adult households

${ }^{23}$ In all tables, the coefficient of $\mathrm{Age}^{2}$ is multiplied by 1000 for a better scaling. 


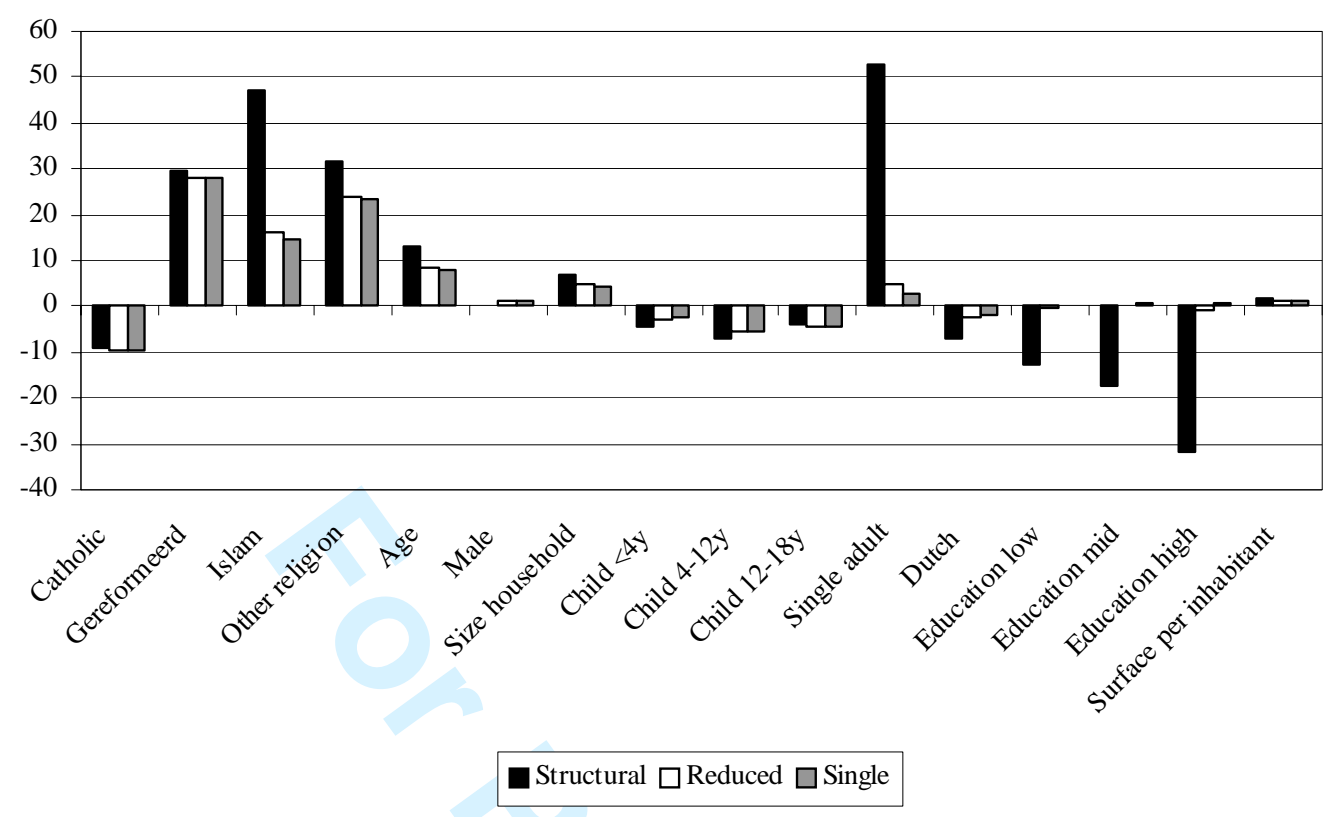

Figure 2: Marginal effects of Participation equation (\%)

and education level. According to Table 6, single-adult households have $46 \%$ less income than households with two grown-ups, while a high education level increases income by $47 \%$.

More interesting are the effects of socio-economic variables on the religious variables (see Panel A in Tables 5 and 6). While Roman Catholic households have a lower religious participation than Reformed households (-9\%: see Table 6), the 'Gereformeerden' and other church members show a higher religious participation (30\% and 32\%, respectively). In contrast, Barro and McCleary (2003) find a higher church attendance for the Roman Catholics than for Protestants, while Sawkins et al. (1997) also find that Catholics have the highest attendance level in Great Britain. The situation in the Netherlands seems to be different from that in other countries. This stresses the point that the dominance of empirical studies based on data for Canada and the USA might be misleading. Furthermore, it questions the soundness of cross-country estimations such as that of Barro and McCleary (2003), as members of the same religion might behave differently in different countries. The relation between age and religious variables is U-shaped, but this effect is only significant for 
the single-equation estimations. The negative effect of children is larger for households with young children as the coefficients for the Child dummies are significantly negative (except for Child $_{<4}$ years in Table 6). Sawkins et al. (1997) find a comparable pattern for Great Britain. However, this conflicts with the results of Barro and McCleary (2003) as they find a positive effect for the share of population younger than 15 on church attendance and an insignificant effect for the share of people older than 65 .

The size of the household has positive effects: larger households are more often members of a church and they also have greater religious participation. These effects are, however, reduced when young children are present. The marginal effects on church membership in Table 5 show that the net effect, when we increase the household size with one and assume that this increase stems from an extra child, is even negative when the youngest child is between 4 and 18 years old. Single-adult households do not attend services more often, nor are they more frequently church members (the coefficients for this variable are not significantly different from zero).

None of the education dummies has a significant effect on membership or participation. Barro and McCleary (2003) find that higher education levels lead to higher levels of religious belief and more church attendance. Sacerdote and Glaeser (2001) argue that households with higher education more often choose to leave the church, but also intensify their religious behavior when they decide to stay. Sawkins et al. (1997) find also a positive effect of education on church attendance. However, we do not find this pattern for the Netherlands. Dutch households are less often members of a church (note that the marginal effect is $-23 \%$ ), although Dutch members attend services as often as non-Dutch members. Finally, households living in less densely populated areas participate more and are also more often members of a church. 


\section{Conclusions}

This paper focuses on the estimation of the effect of religion on income, using a large micro-dataset for the Netherlands. Religion is captured by two measures: church membership and attendance. We find that the estimates of the cross-effects following the single-equation approach differ greatly from the ones obtained from the more efficient system approach.

When religion is measured by membership, we find with the single-equation approach that membership reduces the income level significantly and that income has a negative effect on membership. However, both coefficients become insignificant under simultaneous estimation. The bicausal relation is also rejected when religion is measured by church attendance (for the subset of church members). In contrast, the effects of the socio-economic characteristics on religion and income hardly differ between the estimation approaches.

The conclusion that religion does not affect income, when properly estimated, might be specific for the Dutch situation. For future research we plan to investigate, using micro-datasets, whether the impact of religious behavior differs between countries. 


\section{References}

Azzi, C. and Ehrenberg, R. (1975) Household allocation of time and church attendance, Journal of Political Economy, 83, 27-56.

Barro, R. J. and McCleary, R. (2003) Religion and economic growth across countries, American Sociological Review, 68, 760-81.

Becker, J. W. and De Wit, J. S. J. (2000) Secularisatie in de Jaren Negentig (Secularisation in the Nineties), Social and Cultural Planning Office of the Netherlands, The Hague.

Bettendorf, L. and Dijkgraaf, E. (2005) The bicausal relation between religion and income, Tinbergen Institute Discussion Paper 05-105/2, http://www.tinbergen.nl/scripts/papers.pl?paper=05105.rdf.

Blundell, R. and Smith, R. J. (1994) Coherency and estimation in simultaneous models with censored or qualitative dependent variables, Journal of Econometrics, 64, 355-73.

Chiswick, B. R. (1983) The earnings and human capital of American Jews, Journal of Human Resources, 18, 313-36.

Chiswick, B. R. (1993) The skills and economic status of American Jewry: trends over the last half-century, Journal of Labor Economics, 11, 229-42.

Cornwell, C. M., Tinsley, K. L. and Warren, R. S. (2003) Religious background and the labor supply and wages of young women, University of Georgia, http://www.terry.uga.edu/ cornwl/research/ctw.pdf.

Crain, W. M. and Lee, K. J. (1999) Economic growth regressions for the American states: a sensitivity analysis, Economic Inquiry, 37, 242-57.

De Mooij, R. (2006) Reinventing the Welfare State, Centraal Planbureau, The Hague.

Greene, W. H. (1997) Econometric Analysis, Prentice-Hall, New Jersey.

Gruber, J. (2005) Religious market structure, religious participation, and outcomes: is religion good for you?, Advances in Economic Policy and Analysis, 5, 1-30. 
Hall, B. H., Link, A. N. and Scott, J. T. (2000) Universities as research partners, NBER Working Paper 7643 .

Heath, W. C., Waters, M. S. and Watson, J. K. (1995) Religion and economic welfare: an empirical analysis of state per capita income, Journal of Economic Behavior 6 Organization, 27, 12942 .

Hendrickx, J. (1998) Religious and educational assortive marriage patterns in the Netherlands, 1940-1985, The Netherlands' Journal of Sociology, 12, 5-22.

Iannaccone, L. R. (1994) Progress in the economics of religion, Journal of Institutional and Theoretical Economics, 150, 737-44.

Iannaccone, L. R. (1998) Introduction to the economics of religion, Journal of Economic Literature, 36, 1465-95.

Iannaccone, L. R., Finke, R. and Stark, R. (1997) Deregulating religion: the economics of church and state, Economic Inquiry, 35, 350-64.

Kalmijn, M. (1998) Intermarriage and homogamy: causes, patterns, trends, Annual Review of Sociology, 24, 395-421.

Lelkes, O. (2006) Tasting freedom: happiness, religion and economic transition, Journal of Economic Behavior \& Organization, 59, 173-94.

Lipford, J. W. and Tollison, R. D. (2003) Religious participation and income, Journal of Economic Behavior $\&$ Organization, 51, 249-60.

Maddala, G. S. (1983) Limited-Dependent and Qualitative Variables in Econometrics, Cambridge University Press, Cambridge.

Mangeloja, E. (2005) Economic growth and religious production efficiency, Applied Economics, $37,2349-59$ 
McCleary, R. M. and Barro, R. J. (2006) Religion and economy, Journal of Economic Perspectives, 20, 49-72.

Sacerdote, B. and Glaeser, E. L. (2001) Education and religion, NBER Working Paper 8080.

Sawkins, J. W., Seaman, P. T. and Williams, H. C. S. (1997) Church attendance in Great Britain: an ordered logit approach, Applied Economics, 29, 125-34.

Steen, T. P. (1996) Religion and earnings: evidence from the NLS Youth Cohort, International Journal of Social Economics, 23, 47-58.

Tomes, N. (1984) The effects of religion and denomination on earnings and the returns to human capital, Journal of Human Resources, 19, 472-88.

Tomes, N. (1985) Religion and the earnings function, American Economic Review, 75, 245-50.

Weber, M. (1930) The Protestant Ethic and the Spirit of Capitalism, Allen \& Unwin, London. 


\section{Appendix A System estimation ${ }^{24}$}

The probability that $y_{1 i}=1$ and $y_{2 i}=j$ for observation $i$ is given by

$$
\begin{aligned}
\operatorname{Pr}\left(y_{1 i}=1, y_{2 i}=j\right)= & \operatorname{Pr}\left(y_{1 i}^{*}>0, \mu_{j-1}<y_{2 i}^{*} \leq \mu_{j}\right) \\
= & \operatorname{Pr}\left(v_{1 i}>-\bar{\beta}_{1}^{\prime} x_{i}, \mu_{j-1}-\bar{\beta}_{2}^{\prime} x_{i}<v_{2 i} \leq \mu_{j}-\bar{\beta}_{2}^{\prime} x_{i}\right) \\
= & \operatorname{Pr}\left(v_{1 i}>-\bar{\beta}_{1}^{\prime} x_{i}, v_{2 i} \leq \mu_{j}-\bar{\beta}_{2}^{\prime} x_{i}\right)- \\
& \operatorname{Pr}\left(v_{1 i}>-\bar{\beta}_{1}^{\prime} x_{i}, v_{2 i} \leq \mu_{j-1}-\bar{\beta}_{2}^{\prime} x_{i}\right) \\
= & \Phi_{2}\left(\bar{\beta}_{1}^{\prime} x_{i}, \mu_{j}-\bar{\beta}_{2}^{\prime} x_{i},-\rho\right)-\Phi_{2}\left(\bar{\beta}_{1}^{\prime} x_{i}, \mu_{j-1}-\bar{\beta}_{2}^{\prime} x_{i},-\rho\right)
\end{aligned}
$$

where $\Phi_{2}(a, b, \rho)$ is the cumulative unit bivariate normal distribution with correlation coefficient $\rho$ evaluated at cutoff points $a$ and $b$. Notice that for the two outside classes $(j=1$ or $j=J)$, the expression simplifies to

$$
\begin{aligned}
& \operatorname{Pr}\left(y_{1 i}=1, y_{2 i}=1\right)=\Phi_{2}\left(\bar{\beta}_{1}^{\prime} x_{i}, \mu_{1}-\bar{\beta}_{2}^{\prime} x_{i},-\rho\right) \\
& \operatorname{Pr}\left(y_{1 i}=1, y_{2 i}=J\right)=\Phi\left(\bar{\beta}_{1}^{\prime} x_{i}\right)-\Phi_{2}\left(\bar{\beta}_{1}^{\prime} x_{i}, \mu_{J-1}-\bar{\beta}_{2}^{\prime} x_{i},-\rho\right)
\end{aligned}
$$

where $\Phi$ denotes the univariate standard normal cdf. Analogously, the probability that $y_{1 i}=0$ and $y_{2 i}=j$ is given by

$$
\operatorname{Pr}\left(y_{1 i}=0, y_{2 i}=j\right)=\Phi_{2}\left(-\bar{\beta}_{1}^{\prime} x_{i}, \mu_{j}-\bar{\beta}_{2}^{\prime} x_{i}, \rho\right)-\Phi_{2}\left(-\bar{\beta}_{1}^{\prime} x_{i}, \mu_{j-1}-\bar{\beta}_{2}^{\prime} x_{i}, \rho\right)
$$

The log likelihood function over all observations is obtained by combining the logarithms of the probabilities (A.1) and (A.2):

${ }^{24}$ This appendix is based on Hall et al. (2000, Appendix B), Greene (1997) and Maddala (1983). 
$\ln L=\sum_{i=1}^{N} \sum_{j=1}^{J}\left\{I\left(y_{1 i}=1, y_{2 i}=j\right) \ln \operatorname{Pr}\left(y_{1 i}=1, y_{2 i}=j\right)+I\left(y_{1 i}=0, y_{2 i}=j\right) \ln \operatorname{Pr}\left(y_{1 i}=0, y_{2 i}=j\right)\right\}$

where $I$ indicates a dummy variable that equals 1 when observation $i$ matches the combination of $y_{1}$ and $y_{2}$. Maximizing (A.3) gives the estimates of the structural coefficients $\left(\alpha_{k}, \beta_{k}\right)$, the cutoff points $\left(\mu_{j}\right)$ and the correlation $(\rho)$.

Notice that in the special case with $\rho=0$, the bivariate system separates into the binary Probit and the ordered Probit since $\Phi_{2}(a, b, 0)=\Phi(a) \Phi(b)$. The log likelihood (A.3) simplifies to the sum of the log likelihood functions of the single equations. 


\title{
Appendix B List of variables
}

\author{
Income (decile) \\ Decile of household income (deciles based on equal number of \\ households in the population per class) \\ Membership \\ Dummy $=1$ for membership of a church \\ Member $_{\text {Catholic }}$ \\ Dummy $=1$ for membership of Roman Catholic church \\ Member $_{\text {Reformed }}$ \\ Dummy $=1$ for membership of Reformed church \\ Member $_{\text {Gereformeerd }}$ \\ Dummy $=1$ for membership of 'Gereformeerde' church \\ Member $_{\text {Islam }}$ \\ Dummy $=1$ for membership of Islam \\ Member $_{\text {Other }}$ \\ Dummy $=1$ for membership of some other church \\ Part \\ Dummy $=1$ if service is attended once or more per week \\ Age \\ Male \\ Age of breadwinner \\ Household size \\ Dummy with value $=1$ if breadwinner is male \\ Child $_{<4}$ years \\ Number of persons in household \\ Child $_{4-12}$ years \\ Dummy $=1$ when youngest child is between 0 and 4 \\ Dummy $=1$ when youngest child is between 4 and 12 \\ Child $12-18$ years \\ Dummy $=1$ when youngest child is between 12 and 18 \\ Single-adult household \\ Household has only one grown-up \\ Education $_{\text {low }}$ \\ Breadwinner has education at junior general secondary level \\ Education $_{\text {mid }}$ \\ Breadwinner has education at senior or pre-university general \\ secondary level or at vocational secondary level \\ Education $_{h i g h}$ \\ Breadwinner has education at higher professional or university level \\ Dutch \\ Breadwinner has Dutch nationality \\ Surface per inhabitant \\ Ordered variable based on area of municipality per inhabitant \\ $(1=$ high density (city), $5=$ low density (sparsely populated \\ country village))
}

